\title{
EXPLORING THE ASSOCIATIONS BETWEEN INSTITUTIONAL CONSTRAINTS AND ENTREPRENEUR'S PERCEPTION IN FUTURE BUSINESS CLIMATE
}

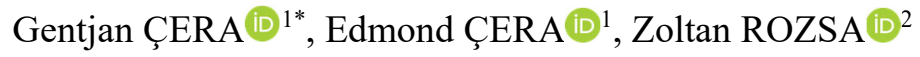 \\ ${ }^{1}$ Department of Business Administration, Faculty of Management and Economics, \\ Tomas Bata University in Zlin, Mostni 5139, 76001 Zlín, Czech Republic \\ ${ }^{2}$ Department of Management, Faculty of Social-Economics Relationship, \\ Alexander Dubcek University of Trencin, Trencin, Slovakia \\ *E-mail: cera@utb.cz
}

\begin{abstract}
Purpose - although many studies emphasise that institutional environment shapes business activity, yet it is not clear enough how legal environment, tax administration and stimulation policies are associated with entrepreneur's perception in the future business climate. This paper seeks to explore these associations in the context of a post-communist transition country.
\end{abstract}

Research methodology - the research takes an institutional perspective, and its analysis is conducted on a firm-level data collection through a face-to-face survey. Kruskal-Wallis test followed up by Jonckheere-Terpstra and Mann-Whitney tests, were employed in a dataset of 404 firms operating in Albania.

Findings - the analysis offers important insights into the nature of entrepreneurship in a post-communist setting. It was found a significant association between future business climate and legal environment and tax administration. Between stimulation policies and business climate was reported an insignificant association. High levels in the legal environment and tax administration lead to the less favourable future business climate.

Research limitations - though Albania has similarities with other transition countries in terms of regional, economic and political environments, the generalisation of these results to another context is limited.

Originality/Value - this research provides insights for scholars studying entrepreneurship in institutional transformation contexts, and it contributes to the accumulation of knowledge on transition countries by focusing on the little-studied case of Albania.

Keywords: entrepreneurship, legal environment, tax administration, stimulation policies, transition country, Albania.

JEL Classification: L26, L53, K23.

Conference topic: Legal Business Environment.

\section{Introduction}

\section{Research problem}

It is widely recognised that entrepreneurship makes a significant contribution to economic growth (Bosma, Content, Sanders, \& Stam, 2018), employment and competitiveness (Chowdhury, Audretsch, \& Belitski, 2018). Also, it is known that firm growth leads to the enhancement of investment and productivity (Dethier, Hirn, \& Straub, 2011), which in turn is affected by the business environment (Krasniqi \& Desai, 2016). Consequently, it can be assumed an association between institutional environment and business climate.

In theory, institutional environment shapes firm behaviour, and it is breakdown into formal and informal institutions (North, 1990). Institutions may enable or constraint entrepreneurial activity. Rules that are communicated through official channels and consist of a regulatory framework and policy tools make formal institutions. In this study, legal environment, tax administration and stimulation policies are part of formal institutions. According to the Business Environment and Enterprise Performance Survey (EBRD, 2017), tax administration was among the top business environment obstacles identified by Albanian entrepreneurs.

Compared to large firms, small and medium-sized enterprises (SMEs) can respond to systemic shock quicker and have the potential to reduce unemployment (Hashi \& Krasniqi, 2011). This makes SMEs vital for transition countries. Figures demonstrate that SMEs play a crucial role in the Albanian economy. They generate about $70 \%$ of the value 
added and above $80 \%$ of employment (European Commission, 2017). Figure 1 illustrates graphically the comparison of employment rate and value added generated by SMEs in the European Union and Albania. Both indicators emphasise that the role of SMEs in Albania is vital for its economy.

No. of persons employed in SMEs

(Index: 2010=100)

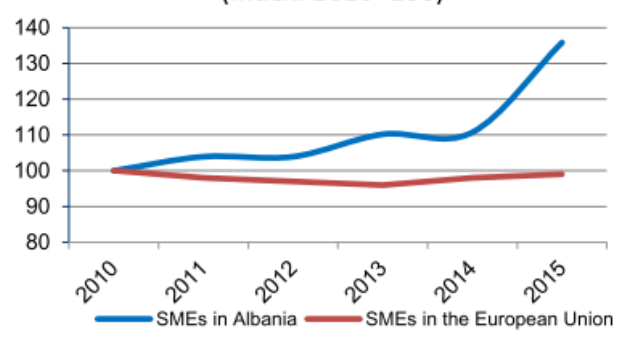

Value added of SMEs

(Index: $2010=100$ )

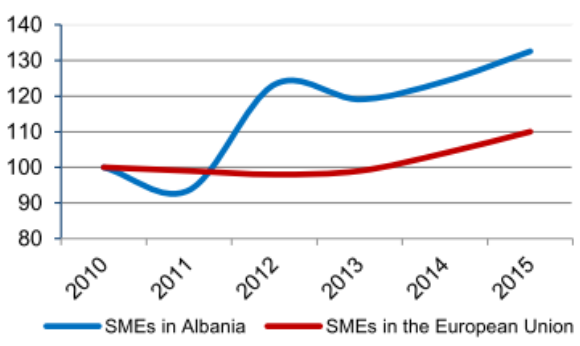

Figure 1. Employment rate and value-added of SMEs (source: European Commission (2017, p. 1))

Formal institutions can be strengthening through a good level of governance. Thai and Turkina (2014) argued that there is a significant positive influence of quality of governance on formal institutions. The current research paper explores the associations between formal instructional constraints, covered mainly by central and local government, and the optimism for future activities within the context of a post-communist developing country such as Albania. Further, being an optimist for the future activities, lead to the perception of the future business climate. Therefore, specific associations of formal institutional constraints and future business climate can be assumed.

\section{Aim}

Even though many studies emphasise that institutional environment shapes business activity, yet it is not clear enough how legal environment, tax administration and government stimulation policies are associated with entrepreneur's perception in the business climate in the near future. To the best of our knowledge, there is a lack of studies examining these associations. The current research seeks to investigate these relationships in the context of post-communist transition Albania. The findings of this paper might be of interest to policymakers aimed at improving constraints related to the legal environment, tax administration and government stimulation policies.

There is no secondary data available covering the Albanian case for the entrepreneurship indicators, so it is not possible to assess its performance and to compare it with other countries (European Commission, 2017). This paper tries to fill this gap by shading light in the relationship between formal institutions and future business climate in the context of a post-communist developing country such as Albania.

The rest of this paper is structured as follow. Next section is dedicated to the literature review aimed at hypotheses developing. Further part covers research strategy consisting of variable measurement, scale reliability, statistical methods, data and sample profile. Then, the empirical results are presented and interpreted. In the final section are discussed the results and given concluding remarks.

\section{Literature review}

Heavily regulated framework and unfriendly business policies may reduce the start-up rate and cannot stimulate individuals from taking actions to start a business (Belás, Demjan, Habánik, Hudáková, \& Sipko, 2015; Chowdhury et al., 2018). Therefore, formal institutional constraints, such as legal environment, tax administration and stimulation policies, might be associated with business climate.

The political environment in a country shapes the entrepreneur's behaviour. Autio and Fu (2015) showed that a good level of political institutions could foster start-up activity. Entrepreneurial cognition is predicted by institutional environment including legal, financial, education and trust systems (Lim, Morse, Mitchell, \& Seawright, 2010). According to Lim et al. (2010), among the institutional factors, the legal environment was found to affect venture arrangements and willingness. In this line, Dai and Si (2018) argued that the effectiveness of new policies positively impacts entrepreneurial orientation. According to a study administrated in $18 \mathrm{EU}$ countries, formal institutions (governmental effectiveness, the rule of law, political stability, voice and accountability, regulatory quality, and control of corruption) positively influence venture capital activity (Economidou, Grilli, Henrekson, \& Sanders, 2018).

Literature in this field suggests that an improvement of the legal environment lead to the efficiency of the economy (Aristovnik \& Obadic, 2015). In this regard, a study demonstrated that the immoderate production of EU legislation had reduced the economic growth of EU countries (Marinescu, 2013). Therefore, the legal framework is important for business activity. Considering the above discussion, a hypothesis can be stated: 
Hypothesis 1a: Business' perception in the legal environment differs across the levels of the future business climate.

Entrepreneur behaviour can be influenced by the level of tax administration applied in a country where they perform their activity. Chowdhury et al. (2018) considered tax rates as a key formal institution that determines entrepreneurship quality. Stallmann and Deller (2011) claimed that the unfavourable business climate and lower economic growth are associated with taxes limitations. Moreover, Braunerhjelm and Eklund (2014) found a negative relationship between administrative tax burden and firm start-ups. Countries which apply burdensome regulations reflect lower rates of start-ups (Aidis, Estrin, \& Mickiewicz, 2012; Verheul, Stel, \& Thurik, 2006) and do not lead to firm growth (Estrin, Korosteleva, \& Mickiewicz, 2013).

Tax administration is reported by entrepreneurs as a problem for their activity in middle-income countries (Dethier et al., 2011). Likewise, firms operating in South East and Central European countries identified tax administration as one of the major obstacles for their activity (Batsakis, 2014; Hashi \& Krasniqi, 2011). Additionally, frequent changes in tax administration are among the most important obstacles identified by Albanian firms (Bitzenis $\&$ Nito, 2005; Xheneti \& Bartlett, 2012). Therefore, we propose this hypothesis:

Hypothesis 1b: Business' perception in tax administration differs across the levels of the future business climate.

Stimulation policies aimed at the improvement of the business environment are considered by the government to stimulate start-up activity and business activity (Brixiova \& Égert, 2017; Fereidouni \& Masron, 2012). The government may enable entrepreneurial activities by designing business stimulation policies or constraint it through applying heavily regulated framework (Cepel, Stasiukynas, Kotaskova, \& Dvorsky, 2018; Cumming, Grilli, \& Murtinu, 2017; Kljucnikov, Belas, Kozubikova, \& Pasekova, 2016; Xheneti \& Smallbone, 2008).

Surfield and Reddy (2016) found that business climate coincides with a lower rate of job loss. According to Blume (2006), the business climate is associated with local government policies. Nevertheless, other researchers claim that in a short-run time spam governments cannot do much to change the business sector profile of a country, while, in a long run, they can make an investment in infrastructure or education, which in turn may influence the economy (Kolko, Neumark, \& Mejia, 2013). Conversely, Xheneti and Bartlett (2012) found that support-related obstacles do not influence Albanian firm growth. Based on the above evidence, the following hypothesis can be written:

Hypothesis 1c: Business' perception in government stimulation policies differs across the levels of the future business climate.

Considering the fact that high levels in formal institutional constraints may lead only to less favourable business climate, we stated the following hypothesis:

Hypothesis 2: There is a descending trend across the levels of the future business climate in the entrepreneur's perception in institutional constraints (legal environment, H2a, tax administration, H2b, and stimulation policies, H2c).

\section{Research strategy}

\subsection{Unit of analysis and variable measurement}

A firm-level survey was administrated, thereby a firm is the unit of analysis. A face-to-face structured interview was conducted with a member of the firm management team. As with Jolley, Lancaster and Gao (2015), the owner, coowner, financial manager, director, deputy director or manager was considered to be the appropriate person to represent the firm's viewpoints.

As mentioned earlier, the paper aims to investigate the association between future business climate and selected business constraints such as legal environment, tax administration and stimulation policies in the context of a transition economy. The future business climate is measured by a single question, which is: While taking into consideration the coming second half of the year, how would you evaluate the situation of your firm? Its possible responses were: [-1] = unfavourable, $[0]=$ normal, and [1] = favourable.

Legal environment and tax administration were composed by the mean of selected item sets both consisting of six statements. This type of variable creation has been widely used in the literature. The six items used to measure legal environment as follows: Business licensing and permits; Customs and trade regulations; Labour regulations; Environmental control authorities; Legislation and procedures for closing up a business, and Public procurement process. Whereas the items for tax administration were: Tax rates; Clarity and understanding of tax legal framework and tax administration procedures; Frequent changes in legislation and tax administration procedures; Frequent staff changes in the tax administration; Tax administration (from Central Tax Administration Department), and Local tax administration (from Local Tax Administration Department). On the other hand, stimulation policies variable was measured by three items, namely Investment stimulation policies; Road infrastructure, and Other infrastructures (including water \& sewerage). Entrepreneurs had to hold a position per each item, by answering to the following request: Please, evaluate to what extent each of the listed statements poses a problem for your business. Subjects had to choose one option between these responses: [1] = Is not a problem, [2] = Minor problem, [3] = Moderate problem, [4] = Major problem, and $[5]=$ Severe problem. 


\subsection{Scale reliability}

Legal environment, stimulation policies and tax administration are composite variables of the six, three and six item sets. Before computing the mean of item sets of composed variables and proceeding with further analysis, the reliability of the scale should be checked. Reliability test checks whether or not the measure reflects the construct that it is measuring.

Table 1 shows the mean, standard deviation per each statement and the result of Cronbach's alpha along with Cronbach's alpha if item deleted. Concerning the legal environment construct, the highest mean was reported for Legal2 = "Customs and trade regulations" equal to 2.43, while the lowest one was for Legal3 = "Labour regulations", which was 1.62. The highest standard deviation was accounted for Legal5 = "Legislation \& procedures for closing up a business" equals to 1.462 , while the lowest one was noticed for Legal3 = "Labour regulations", which was 0.984 . On the other hand, the mean and standard deviation of stimulation policies construct was reported 2.75 , and 1.173, respectively. The highest mean and standard deviation among its three items was identified Stim1 = "Investment stimulation policies" equalled to 3.07 and 1.472 , respectively.

Regarding the tax administration construct, the lowest mean was accounted for Tax6 = "Local tax administration (from Local Tax Administration Department)" equalled to 2.11 with a standard deviation of 1.293. Here, mean can be interpreted in terms of the maximum value an item could take, which was 5 (severe problem). So, a figure close to 1 tends to show that that statement is not perceived as a problem, while a value close to 5 inform for a severe problem.

Table 1. Descriptive statistics and reliability test

\begin{tabular}{|c|l|c|c|c|c|}
\hline Item & \multicolumn{1}{|c|}{ Legal environment-related constraints } & Mean & $\begin{array}{c}\text { Std. } \\
\text { deviation }\end{array}$ & $\begin{array}{c}\text { Cronbach's } \\
\text { alpha }\end{array}$ & $\begin{array}{c}\text { Cronbach's alpha } \\
\text { if item deleted }\end{array}$ \\
\hline & \multicolumn{1}{|c|}{ (1) } & 0.845 & 0.761 & - \\
\hline Legal1 & Business licensing and permits & 1.65 & 1.118 & & 0.761 \\
\hline Lega12 & Customs and trade regulations & 2.43 & 1.407 & & 0.715 \\
\hline Legal3 & Labor regulations & 1.62 & 0.984 & & 0.731 \\
\hline Legal4 & Environmental control authorities & 1.92 & 1.162 & & 0.724 \\
\hline Lega15 & Legislation \& procedures for closing up a business & 2.34 & 1.462 & & 0.728 \\
\hline Lega16 & Public procurement process & 2.20 & 1.448 & & 0.690 \\
\hline & \multicolumn{1}{|c|}{ Stimulation policies-related constraints } & 2.75 & 1.173 & 0.683 & - \\
\hline Stim1 & Investment stimulation policies & 3.07 & 1.472 & & 0.641 \\
\hline Stim2 & Road infrastructure & 2.97 & 1.449 & & 0.547 \\
\hline Stim3 & Other infrastructures (including water \& sewerage) & 2.37 & 1.410 & & 0.578 \\
\hline & \multicolumn{1}{|c|}{ Tax administration-related constraints } & 2.60 & 1.073 & 0.866 & - \\
\hline Tax1 & Tax rates & 3.15 & 1.353 & & 0.857 \\
\hline Tax2 & $\begin{array}{l}\text { Clarity and understanding of tax legal framework and tax admin- } \\
\text { istration procedures }\end{array}$ & 2.53 & 1.409 & & 0.839 \\
\hline Tax3 & $\begin{array}{l}\text { Frequent changes in legislation and tax administration proce- } \\
\text { dures }\end{array}$ & 3.07 & 1.466 & & 0.841 \\
\hline Tax4 & Frequent staff changes in the tax administration & 2.49 & 1.471 & & 0.846 \\
\hline Tax5 & $\begin{array}{l}\text { Tax administration (from Central Tax Administration Depart- } \\
\text { ment) }\end{array}$ & 2.12 & 1.287 & & 0.830 \\
\hline Tax6 & $\begin{array}{l}\text { Local tax administration (from Local Tax Administration De- } \\
\text { partment) }\end{array}$ & 2.11 & 1.293 & & 0.849 \\
\hline
\end{tabular}

Referring to DeVellis's (2017) criteria, legal environment was respectable, since the Cronbach's alpha value is between 0.70 and 0.80 . Moreover, the removal of any item from this scale does not lead to a higher Cronbach's alpha (see the last column of Table 1). A very good internal consistency was reported for the tax administration construct, as its Cronbach's alpha was equal to 0.866 (ranges in between 0.8 to 0.9 ). Cronbach's alpha of stimulation policies was minimally acceptable (0.683). Therefore, the usage of the composite variables of legal environment, tax administration and stimulation policies in further analysis and their obtained results do not mislead since the internal consistency of the scales were reported above undesirable level (DeVellis, 2017).

\subsection{Statistical tests}

The aim of this paper was to explore whether the entrepreneur's perception legal environment, tax administration and stimulation policies across the future business climate levels or not. To test this, a one-way between-subjects analysis of variance (ANOVA) should apply. However, the assumptions of ANOVA were violated, which implies the use of 
the Kruskal-Wallis H test. This test allows scholars to compare the scores on one or several continuous variables for three or more groups. After scores are converted to ranks, the mean rank for each group is compared. To obtain this statistic, the ranks in each category are added to get a total or $T$ value for that category. The number of firms in each category is identified by the letter $n$ (lowercase). The total number of subjects in the entire study is shown by the letter $N$ (uppercase) (Gravetter \& Wallnau, 2017), as follow:

$$
H=\frac{12}{N(N+1)} \Sigma \frac{T^{2}}{n}-3(N+1) .
$$

In addition, the comparing categories of future business climate produce a meaningful order of medians. To test for trends in future business climate categories (ordinal variable), the Jonckheere-Terpstra test was performed. If the sample is large, then it has a normal distribution, which means that $z$ score can be calculated and interpreted. A negative/positive $z$ score indicates a trend of descending/ascending medians (Field, 2009). The strength of the effect is calculated as the division of $z$ score with the square root of sample size including all groups. To judge this effect size, Cohen's (1988) criteria were applied: .01, .30 and .50 for a small, medium and large effect.

To test for differences between future business climates categories (in pair) on legal environment, tax administration and stimulation policies, Mann-Whitney $U$ test were used. The assumptions of applying t-test were not met, which imply the use of the Mann-Whitney U test. Compared to the Kruskal-Wallis H test, Mann-Whitney U test analysis the difference only between two groups. Its effect size can be calculated and interpreted similarly to the case of the Jonckheere-Terpstra test since it has a $z$ score for each $U$ value. U statistic formula incorporates the number of the subject per each category and the sum of the ranks $(R)$ for individuals in the respective sample, and between the following calculations, the lowest one represents the Mann-Whitney U value.

$$
\begin{gathered}
U_{1}=n_{1} n_{2}+\frac{n_{1}\left(n_{1}+1\right)}{2}-\sum R_{1} \\
U_{2}=n_{1} n_{2}+\frac{n_{2}\left(n_{2}+1\right)}{2}-\sum R_{2}
\end{gathered}
$$

The Mann-Whitney U can be standardised using the following formula:

$$
z=\frac{U-\left(n_{1} n_{2} / 2\right)}{\sqrt{n_{1} n_{2}\left(n_{1}+n_{2}+1\right) / 12}} .
$$

The three tests explained above are nonparametric methods (Hollander, Wolfe, \& Chicken, 2013).

\subsection{Data and sample profile}

The data shown and analysed in this study were obtained by a survey conducted with business owners, managers or finance supervisors of firms operating in Albania. The sample distribution ensured representation of all businesses in the country in terms of region and sector dimension. Overall, 404 businesses took part in the survey. More than half of the interviews $(57.9 \%$ ) were conducted in the capital city, about $22.8 \%$ of the interviews in South region, $11.4 \%$ in the central region of Albania and the other part of the interviews were conducted in the north region (see Table 2).

Table 2. Sample profile

\begin{tabular}{|l|l|c|c|}
\hline \multirow{4}{*}{ Sector } & & Frequency & Per cent \\
\hline \multirow{4}{*}{ Region } & Manufacturing & 81 & 20.0 \\
\cline { 2 - 4 } & Services & 161 & 39.9 \\
\cline { 2 - 4 } & Trade & 162 & 40.1 \\
\hline \multirow{5}{*}{ Firm age } & South & 92 & 22.8 \\
\cline { 2 - 4 } & North & 32 & 7.9 \\
\cline { 2 - 4 } & Central & 46 & 11.4 \\
\cline { 2 - 4 } & Capital city (Tirana) & 234 & 57.9 \\
\hline \multirow{3}{*}{ Future business climate } & Less than 5 year & 132 & 32.8 \\
\cline { 2 - 4 } & More than 5 years & 270 & 67.2 \\
\cline { 2 - 4 } & Unfavourable & 189 & 47.7 \\
\cline { 2 - 4 } & Normal & 139 & 35.1 \\
\cline { 2 - 4 } & Favourable & 68 & 17.2 \\
\hline
\end{tabular}


Concerning the business sector, about $20 \%$ of the businesses part of the survey were manufacture, $39.9 \%$ of businesses in service and $40.1 \%$ were part of the trade sector (see Table 2). About two in three respondents were part of businesses which had more than five years operating in the market. When asked to evaluate the situation of their firm, about $47.7 \%$ of them declared that the future business climate was unfavourable. This means that almost half of the firms perceived an unfavourable business climate in the near future. On the other hand, only $17.2 \%$ of the firms have a favourable perception regarding the future business climate.

\section{Results}

To estimate the Kruskal-Wallis test, the number of observations and mean rank per each category of future business climate should be calculated. These are shown per each constraint (Legal environment, Tax administration, and Stimulation policies) in Table 3. The observation distribution of legal environment per each category of future business climate were 189 for unfavourable, 139 for normal, and 68 for favourable. This distribution is the same even for two other constraints. Their mean ranks for legal environment construct were reported 217.55 for unfavourable, 196.45 for normal, and 149.74 for the favourable category. Regarding tax administration construct, the mean ranks were 213.06, 204.8 and 145.15 for unfavourable, normal and favourable categories. Turning to stimulation policies constraint, the mean ranks were a bit lower than two other constraints for the two first categories of future business climate (212.08 and 185.15), and a bit higher for the last category (184.93). The information concerning mean ranks of the three constraints per each future business climate category is used to calculate the Kruskal-Wallis test.

Table 3. Mean ranks per each variable by future business climate levels

\begin{tabular}{|l|l|c|c|}
\hline Related constraints & Future business climate & N & Mean Rank \\
\hline \multirow{4}{*}{ Legal environment } & Unfavourable & 189 & 217.55 \\
\cline { 2 - 4 } & Normal & 139 & 196.45 \\
\cline { 2 - 4 } & Favourable & 68 & 149.74 \\
\cline { 2 - 4 } & \multicolumn{1}{|c|}{ Total } & 396 & \\
\hline \multirow{5}{*}{ Tax administration } & Unfavourable & 189 & 213.06 \\
\cline { 2 - 4 } & Normal & 139 & 204.80 \\
\cline { 2 - 4 } & Favourable & 68 & 145.15 \\
\cline { 2 - 4 } & & 396 & \\
\hline \multirow{5}{*}{ Stimulation policies } & Total & 189 & 212.08 \\
\cline { 2 - 4 } & Unfavourable & 139 & 185.15 \\
\cline { 2 - 4 } & Normal & 67 & 184.93 \\
\cline { 2 - 4 } & Favourable & 395 & \\
\cline { 2 - 4 } & Total & & \\
\hline
\end{tabular}

Table 4 summaries the results of the Kruskal-Wallis and Jonckeheere-Terpstra tests for future business climate per each constraint: legal environment, tax administration and stimulation policies. The future business climate is an ordinal variable with three levels or categories, which are in ascending. Therefore a test that identifies whether is a trend or not across the future business climate categories in three constructed variables.

The Kruskal-Wallis test revealed that there was an association between future business climate and legal environment and tax administration-related constraints. Thus, business' perception on legal environment $(H(2, n=396)=$ $17.788, p<0.001)$ and tax administration $(H(2, n=396)=18.288, p<0.001)$ differs across the future business climate categories. The significance of the association between future business climate and stimulation policies was below the edge of critic level equalled to $5 \%(H(2, n=395)=5.548, p=0.062)$. Thereby, the evidence failed to reject $\mathrm{H} 1 \mathrm{a}, \mathrm{H} 1 \mathrm{~b}$ but did not support H1c.

As mentioned earlier, to follow up on the Kruskal-Wallis test results, the Jonckheere-Terpstra test was conducted. It found a statistical significance ascending trend in the data in cases of three constructed variables. Thus, the score in the legal environment $(J=19567, z=-3.928, p<0.001, r=-0.197)$ and tax administration reflected $(J=20077$, $z=-3.491, p<0.001, r=-0.175$ ) a descending trend across the categories of future business climate (unfavourable, normal, and favourable). Contrary to the Kruskal-Wallis test, the significance of the trend related to the case of stimulation policies was reported, $J=21458, z=-2.224, p=0.026, r=-0.112$. Looking at the standardised JonckheereTerpstra statistic, as more favourable the future business climate was, the entrepreneur's perception in the legal environment, tax administration and stimulation policies were descending. This is logical since the three composed variables were measured as constraints. The higher the problems (constraints' level), the lower the level of being an optimist for the future. Concerning the effect size, the $r$ statistic showed a small to medium effect in all cases. All things considered, the evidence supported $\mathrm{H} 2 \mathrm{a}, \mathrm{H} 2 \mathrm{~b}$ and $\mathrm{H} 2 \mathrm{c}$. 
Table 4. Results of Kruskal-Wallis and Jonckheere-Terpstra Tests

\begin{tabular}{|l|c|c|c|c|}
\hline \multirow{2}{*}{ Test } & \multirow{2}{*}{ Statistics } & \multicolumn{3}{|c|}{ Related constraints } \\
\cline { 2 - 5 } & Legal environment & Tax administration & Stimulation policies \\
\hline \multirow{3}{*}{ Kruskal Wallis } & Chi-Square & 17.788 & 18.288 & 5.548 \\
& $\mathrm{df}$ & 2 & 2 & 2 \\
& Asymp. Sig. & .000 & .000 & .062 \\
\cline { 2 - 5 } Jonckheere-Terpstra & $\mathrm{N}$ & 396 & 396 & 395 \\
& Observed J-T Statistic & 19567 & 20077 & -2.224 \\
& Std. J-T Statistic & -3.928 & -3.491 & .026 \\
& Asymp. Sig. (2-tailed) & .000 & .000 & -0.112 \\
\hline
\end{tabular}

Note: Grouping variable: Future business climate.

To test whether it is a difference between the future business climate levels or not, Mann-Whitney U test was performed (refer to Regarding tax administration-related constraints, the Mann-Whitney test showed that, subjects scored on it statistically different between normal and favourable $(U=3267, z=-3.609, p<0.001, r=-0.225)$, and unfavourable and favourable levels of future business climate $(U=4257.5, z=-4.130, p<0.001, r=-0.287)$. However, it was an insignificance difference in tax administration between unfavourable and normal categories of future business climate $(U=12552.5, z=-0.688, p=0.492, r=-0.038)$. Compared to unfavourable future business climate level, entrepreneurs that perceived business climate as normal or favourable scored lower on tax administration (167.58 vs 160.31 and 140.47 vs 97.11). In addition, they had higher scores on tax administration in the normal level of future business climate when compared to favourable level (114.5 vs 82.54). The strength of the effects was close to medium size.

Turning into stimulation policies-related constraints, the Mann-Whitney test found contrary results compared to the two other composited variables. Hence, entrepreneur's perception on stimulation policies was statistically different between unfavourable and normal levels of future business climate $(U=11345.5, z=-2.116, p=0.034, r=-0$. 117). On the other hand, there was no statistical differences between normal and favourable levels $(U=4652, z=-0.011$, $p>0.1, r=-0.001)$, and unfavourable and favourable levels of future business climate $(U=5460.5, z=-1.677$, $p>0.05, r=-0.117)$. Business owners that perceived future business climate as normal or favourable scored lower on stimulation policies (173.97 vs 151.62 and 133.11 vs 115.50$)$ when compared to unfavourable level.

Table 5). It revealed that, legal environment was statistically significant different between normal and favourable categories $(U=3605.5, z=-2.789, p=0.005, r=-0.092)$, and between unfavourable and favourable categories of future business climate $(U=4231, z=-4.198, p<0.001, r=-0.174)$. On the other hand, it was not reported any high significance of the difference between unfavourable and normal levels of future business climate $(U=11730.5$, $z=-1.662, p>0.05, r=-0.292$ ). A close look at their mean ranks leads to the clarification of the different direction. Businesses scored higher in a legal environment when the future business climate was perceived unfavourable than it was normal, normal compared to favourable, and unfavourable compared to favourable level. The effect size resulted in small to medium size.

Regarding tax administration-related constraints, the Mann-Whitney test showed that, subjects scored on it statistically different between normal and favourable $(U=3267, z=-3.609, p<0.001, r=-0.225)$, and unfavourable and favourable levels of future business climate $(U=4257.5, z=-4.130, p<0.001, r=-0.287)$. However, it was an insignificance difference in tax administration between unfavourable and normal categories of future business climate $(U=12552.5, z=-0.688, p=0.492, r=-0.038)$. Compared to unfavourable future business climate level, entrepreneurs that perceived business climate as normal or favourable scored lower on tax administration (167.58 vs 160.31 and 140.47 vs 97.11). In addition, they had higher scores on tax administration in the normal level of future business climate when compared to favourable level (114.5 vs 82.54). The strength of the effects was close to medium size.

Turning into stimulation policies-related constraints, the Mann-Whitney test found contrary results compared to the two other composited variables. Hence, entrepreneur's perception on stimulation policies was statistically different between unfavourable and normal levels of future business climate $(U=11345.5, z=-2.116, p=0.034, r=-0$. 117). On the other hand, there was no statistical differences between normal and favourable levels $(U=4652, z=-0.011$, $p>0.1, r=-0.001)$, and unfavourable and favourable levels of future business climate $(U=5460.5, z=-1.677$, $p>0.05, r=-0.117)$. Business owners that perceived future business climate as normal or favourable scored lower on stimulation policies (173.97 vs 151.62 and 133.11 vs 115.50$)$ when compared to unfavourable level. 

future business climate

Table 5. Results of the Mann-Whitney test

\begin{tabular}{|c|c|c|c|c|c|c|c|c|}
\hline \multirow{2}{*}{ Related constraints } & \multicolumn{3}{|c|}{ Mean rank } & \multirow{2}{*}{$n$} & \multicolumn{4}{|c|}{ Mann-Whitney test } \\
\hline & Unfavourable & Normal & Favourable & & $U$ & $z$ & Sig. & $r$ \\
\hline \multirow[t]{3}{*}{ Legal environment } & 171.93 & 154.39 & - & 328 & 11730.5 & -1.662 & 0.097 & -0.092 \\
\hline & - & 112.06 & 87.52 & 257 & 3605.5 & -2.789 & 0.005 & -0.174 \\
\hline & 140.61 & - & 96.72 & 207 & 4231 & -4.198 & 0.000 & -0.292 \\
\hline \multirow[t]{3}{*}{ Tax administration } & 167.58 & 160.31 & - & 328 & 12552.5 & -0.688 & 0.492 & -0.038 \\
\hline & - & 114.50 & 82.54 & 257 & 3267 & -3.609 & 0.000 & -0.225 \\
\hline & 140.47 & - & 97.11 & 207 & 4257.5 & -4.130 & 0.000 & -0.287 \\
\hline \multirow[t]{3}{*}{ Stimulation policies } & 173.97 & 151.62 & - & 328 & 11345.5 & -2.116 & 0.034 & -0.117 \\
\hline & - & 103.53 & 103.43 & 256 & 4652 & -0.011 & 0.991 & -0.001 \\
\hline & 133.11 & - & 115.50 & 206 & 5460.5 & -1.677 & 0.093 & -0.117 \\
\hline
\end{tabular}

\section{Concluding remarks}

Entrepreneurship is seen by academics and policymakers as an important factor in promoting economic growth and reducing unemployment rate (Bosma et al., 2018; Chowdhury et al., 2018). Thus, many advanced and developing economies have formulated policies aimed at supporting entrepreneurial activity. Nevertheless, due to the differences in regional, historical, economic and institutional environments, the influence of enterprise policies development and implementation on entrepreneurship varies across countries. This research focuses only on the association of selected formal institutional constraints and future business climate in the context of a post-communist transition economy.

The study takes an institutional perspective (Baumol, 1990; North, 1990; Williamson, 2000) and seeks to explore the associations between institutions and business behaviour. This theory argues that the role of formal institutional constraints is essential for the entrepreneur's behaviour, particularly for emerging and transition economies. Such institutions include legal environment, tax administration and stimulation policies. Compared to advanced economies, quality of institutions has a greater influence on entrepreneurship in developing countries (Krasniqi \& Desai, 2016).

This study showed that the association between formal institutional constraints and the future business climate is present even in case of a post-communist transition country such as Albania. Moreover, it was found a significant association between legal environment and tax administration, on the one hand, and the future business climate. These findings are consistent with previous studies (Brixiova \& Égert, 2012, 2017; Chowdhury et al., 2018). Surprisingly, the association between stimulation policies and future business climate was found insignificant. This goes in line with previous research (Čadil, Mirošník, \& Rehák, 2017), even conducted for Albanian case (Xheneti \& Bartlett, 2012). As can be expected, high levels in the legal environment and tax administration lead to the less favourable future business climate. Therefore, heavily regulated framework and unfriendly business policies constraint entrepreneurial activity and can discourage individuals from engaging with business start-up (Chowdhury et al., 2018).

Even though this research paper has reached its aims, there are limitations in research. First, our findings are limited to one country, which might share the same with a limited number of countries. Therefore, our conclusions can be generalised only for developing and transition countries, sharing similar economic, institutional and political environments with Albania.

The findings of the current research are useful for designing policies aimed at the encouragement of entrepreneurial activity and improving the business climate. The results are beneficial for policymakers since significant associations between future business climate and institutional constraints were found. Consequently, this study adds value to the entrepreneurship literature.

\section{Funding}

This work was supported by the Internal Grant Agency of Univerzita Tomáše Bati ve Zlíně, under Grant IGA/FaME/2019/002, title "The role of institutional environment in fostering entrepreneurship".

\section{Contribution}

Conceptualisation, the design of the work, analysis and interpretation of the data are covered by Gentjan Çera, data collection, a part of analyses and the revising process are done by Edmond Çera and Zoltan Rozsa. 
Çera, G.; Çera, E.; Rozsa, Z. 2019. Exploring the associations between institutional constraints and entrepreneur's perception in future business climate

\section{Disclosure statement}

This research paper does not have any competing financial, professional or personal interests from other parties.

\section{References}

Aidis, R., Estrin, S., \& Mickiewicz, T. M. (2012). Size matters: entrepreneurial entry and government. Small Business Economics, 39(1), 119-139. https://doi.org/10.1007/s11187-010-9299-y

Aristovnik, A., \& Obadic, A. (2015). The impact and efficiency of public administration excellence on fostering SMEs in EU countries. Amfiteatru Economic, 17(39), 761-774.

Autio, E., \& Fu, K. (2015). Economic and political institutions and entry into formal and informal entrepreneurship. Asia Pacific Journal of Management, 32(1), 67-94. https://doi.org/10.1007/s10490-014-9381-0

Batsakis, G. K. (2014). Impediments on the way to entrepreneurship. Some new evidence from the EU's post-socialist world. Journal of Small Business and Enterprise Development, 21(3), 385-402. https://doi.org/10.1108/JSBED-04-2014-0062

Baumol, W. J. (1990). Entrepreneurship: Productive, unproductive, and destructive. Journal of Political Economy, 98(5, Part 1), 893-921. https://doi.org/10.1086/261712

Belás, J., Demjan, V., Habánik, J., Hudáková, M., \& Sipko, J. (2015). The business environment of small and medium-sized enterprises in selected regions of the Czech Republic and Slovakia. E+M Ekonomie a Management, 18(1), 95-110. https://doi.org/10.15240/tul/001/2015-1-008

Bitzenis, A., \& Nito, E. (2005). Obstacles to entrepreneurship in a transition business environment: the case of Albania. Journal of Small Business and Enterprise Development, 12(4), 564-578. https://doi.org/10.1108/14626000510628234

Blume, L. (2006). Local economic policies as determinants of the local business climate: Empirical results from a cross-section analysis among East German municipalities. Regional Studies, 40(4), 321-333. https://doi.org/10.1080/00343400600725178

Bosma, N., Content, J., Sanders, M., \& Stam, E. (2018). Institutions, entrepreneurship, and economic growth in Europe. Small Business Economics, 51(2), 483-499. https://doi.org/10.1007/s11187-018-0012-x

Braunerhjelm, P., \& Eklund, J. E. (2014). Taxes, tax administrative burdens and new firm formation. Kyklos, 67(1), 1-11. https://doi.org/10.1111/kykl.12040

Brixiova, Z., \& Égert, B. (2017). Entrepreneurship, institutions and skills in low-income countries. Economic Modelling, 67, 381391. https://doi.org/10.1016/j.econmod.2017.02.020

Brixiová, Z., \& Égert, B. (2012). Business environment, start-ups, and productivity during the transition. Macroeconomic Dynamics, 16(S2), 213-231. https://doi.org/10.1017/S1365100511000344

Čadil, J., Mirošník, K., \& Rehák, J. (2017). The lack of short-term impact of cohesion policy on the competitiveness of SMEs. International Small Business Journal: Researching Entrepreneurship, 35(8), 991-1009. https://doi.org/10.1177/0266242617695382

Cepel, M., Stasiukynas, A., Kotaskova, A., \& Dvorsky, J. (2018). Business environment quality index in the SME segment. Journal of Competitiveness, 10(2), 21-40. https://doi.org/10.7441/joc.2018.02.02

Chowdhury, F., Audretsch, D. B., \& Belitski, M. (2018). Institutions and Entrepreneurship Quality. Entrepreneurship Theory and Practice, 1-31. https://doi.org/10.1177/1042258718780431

Cohen, J. (1988). Statistical power analysis for the behavioural sciences (2nd ed.). L. Erlbaum Associates.

Cumming, D. J., Grilli, L., \& Murtinu, S. (2017). Governmental and independent venture capital investments in Europe: A firmlevel performance analysis. Journal of Corporate Finance, 42, 439-459. https://doi.org/10.1016/j.jcorpfin.2014.10.016

Dai, W., \& Si, S. (2018). Government policies and firms' entrepreneurial orientation: Strategic choice and institutional perspectives. Journal of Business Research, 93, 23-36.https://doi.org/10.1016/j.jbusres.2018.08.026

Dethier, J.-J., Hirn, M., \& Straub, S. (2011). Explaining enterprise performance in developing countries with business climate survey data. The World Bank Research Observer, 26(2), 258-309. https://doi.org/10.1093/wbro/lkq007

DeVellis, R. F. (2017). Scale development: theory and applications ( $4^{\text {th }}$ ed.). SAGE Publications.

Economidou, C., Grilli, L., Henrekson, M., \& Sanders, M. (2018). Financial and Institutional reforms for an entrepreneurial society. Small Business Economics, 51(2), 279-291. https://doi.org/10.1007/s11187-018-0001-0

Estrin, S., Korosteleva, J., \& Mickiewicz, T. (2013). Which institutions encourage entrepreneurial growth aspirations? Journal of Business Venturing, 28(4), 564-580. https://doi.org/10.1016/j.jbusvent.2012.05.001

European Bank for Reconstruction and Development (EBRD). (2017). The business environment in the transition region (Vol. 14). London.

European Commission. (2017). European Neighbourhood Policy and Enlargement Negotiations: 2017 SBA Fact Sheet Albania. Brussel.

Fereidouni, H. G., \& Masron, T. A. (2012). Governance Matters and Entrepreneurial Activities. Thunderbird International Business Review, 54(5), 701-712. https://doi.org/10.1002/tie.21494

Field, A. (2009). Discovering statistics using SPSS ( $3^{\text {rd }}$ ed.). SAGE.

Gravetter, F. J., \& Wallnau, L. B. (2017). Statistics for the behavioural sciences (10 ${ }^{\text {th }}$ ed.). CENGAGE Learning.

Hashi, I., \& Krasniqi, B. A. (2011). Entrepreneurship and SME growth: evidence from advanced and laggard transition economies. International Journal of Entrepreneurial Behavior \& Research, 17(5), 456-487. https://doi.org/10.1108/13552551111158817 
Çera, G.; Çera, E.; Rozsa, Z. 2019. Exploring the associations between institutional constraints and entrepreneur's perception in future business climate

Hollander, M., Wolfe, D. A., \& Chicken, E. (2013). Nonparametric statistical methods (3 ${ }^{\text {rd }}$ ed.). Wiley.

Jolley, G. J., Lancaster, M. F., \& Gao, J. (2015). Tax incentives and business climate: Executive perceptions from incented and nonincented firms. Economic Development Quarterly, 29(2), 180-186. https://doi.org/10.1177/0891242415571127

Kljucnikov, A., Belas, J., Kozubikova, L., \& Pasekova, P. (2016). The entrepreneurial perception of SME business environment quality in the Czech Republic. Journal of Competitiveness, 8(1), 66-78. https://doi.org/10.7441/joc.2016.01.05

Kolko, J., Neumark, D., \& Mejia, M. C. (2013). What do business climate indexes teach us about state policy and economic growth? Journal of Regional Science, 53(2), 220-255. https://doi.org/10.1111/j.1467-9787.2012.00782.x

Krasniqi, B. A., \& Desai, S. (2016). Institutional drivers of high-growth firms: country-level evidence from 26 transition economies. Small Business Economics, 47(4), 1075-1094. https://doi.org/10.1007/s11187-016-9736-7

Lim, D. S. K., Morse, E. A., Mitchell, R. K., \& Seawright, K. K. (2010). Institutional environment and entrepreneurial cognitions: A comparative business systems perspective. Entrepreneurship Theory and Practice, 34(3), 491-516. https://doi.org/10.1111/j.1540-6520.2010.00384.x

Marinescu, C. (2013). Institutional quality of the business environment: Some European practices in a comparative analysis. Amfiteatru Economic, 15(33), 270-287.

North, D. C. (1990). Institutions, institutional change, and economic performance. Cambridge University Press. https://doi.org/10.1017/CBO9780511808678

Stallmann, J. I., \& Deller, S. (2011). State Tax and expenditure limitations, business climate, and economic performance. Public Budgeting \& Finance, 31(4), 109-135. https://doi.org/10.1111/j.1540-5850.2011.00995.x

Suffield, C. J., \& Reddy, C. S. (2016). Mass layoffs, manufacturing and state business climates: Does state policy matter? Contemporary Economic Policy, 34(4), 630-645. https://doi.org/10.1111/coep.12157

Thai, M. T. T., \& Turkina, E. (2014). Macro-level determinants of formal entrepreneurship versus informal entrepreneurship. Journal of Business Venturing, 29(4), 490-510. https://doi.org/10.1016/j.jbusvent.2013.07.005

Verheul, I., Stel, A. Van, \& Thurik, R. (2006). Explaining female and male entrepreneurship at the country level. Entrepreneurship \& Regional Development, 18(2), 151-183. https://doi.org/10.1080/08985620500532053

Williamson, O. E. (2000). The new institutional economics: Taking stock, looking ahead. Journal of Economic Literature, 38(3), 595-613. https://doi.org/10.1257/jel.38.3.595

Xheneti, M., \& Bartlett, W. (2012). Institutional constraints and SME growth in post-communist Albania. Journal of Small Business and Enterprise Development, 19(4), 607-626. https://doi.org/10.1108/14626001211277424

Xheneti, M., \& Smallbone, D. (2008). The role of public policy in entrepreneurship development in post-socialist countries: A comparison of Albania and Estonia. EBS Review, 24, 23-36. 